\title{
Optimization-based analysis of integrated lignocellulosic biorefineries in Spain focusing on building blocks
}

\author{
Silvia Rodriguez-Fernandez ${ }^{1}$. Ismael Díaz ${ }^{1}$ María González-Miquel ${ }^{1} \cdot$ Emilio J. González $^{1}$. Manuel Rodriguez ${ }^{1}$ (D)
}

Received: 6 October 2021 / Revised: 14 December 2021 / Accepted: 18 December 2021

(c) The Author(s) 2022

\begin{abstract}
Spain, in the framework of the European Green Deal, has set ambitious climate and energy goals for 2030. Lignocellulosic biorefineries can make a strong contribution to these goals; however, advanced biofuels generally cannot be produced in a profitable way compared to fossil and first-generation fuels. To address this problem, the efficient production of a wide range of bioproducts, not only biofuels and bioenergy, may be the solution. Therefore, a systematic evaluation of the near-term economic potential bio-building blocks (xylitol, sorbitol, succinic, glutamic, glucaric, levulinic, lactic, and itaconic acids) is presented. Many possible combinations of feedstock and conversion technologies can be considered feasible pathways to manufacture advanced biofuels and bio-based building blocks. To map the optimal groups of technologies in the framework of Spain's biorefineries, we apply a methodology based on a network optimization approach that combines minimum cost and energy criteria together with feedstock availability and demand constraints. The feedstocks analyzed are pine and eucalyptus residues and olive tree pruning wastes, being three largely available agroforesty residues in Spain. The results show that building blocks show good economic and energy performance compared to advanced transportation biofuels, and although their demand is much lower, they should be considered to improve the profitability of biorefineries. Secondly, advanced gasoline, bioethanol, hydrogen, and building blocks demands can be satisfied with pine, eucalyptus, and olive residues available in Spain. Finally, lactic acid production is profitable, but the remaining routes do not reach the break-even point, suggesting that further research is still needed.
\end{abstract}

Keywords Lignocellulosic biomass $\cdot$ Superstructure optimization $\cdot$ Building block $\cdot$ Biorefinery

\section{Introduction}

Shifting society's dependence from petroleum-based to renewable biomass-based resources is generally viewed as the key to the development of a sustainable industrial society, energy independence, and effective management of greenhouse gas emissions [1]. Faced with the need to reduce greenhouse gas emissions, Spain, in the framework of the European Green Deal and the Paris Agreement, has set ambitious climate and energy targets for 2030, including a target for renewable energy of at least $42 \%$ of final gross energy consumption [2] and lignocellulosic biorefineries

Manuel Rodriguez

manuel.rodriguezh@upm.es

1 Departamento de Ingeniería Química Industrial Y del Medioambiente, Escuela Superior de Ingenieros Industriales, Universidad Politécnica de Madrid, C/ José Gutiérrez Abascal 2, 28006 Madrid, Spain can contribute significantly to this goal. The Paris Agreement sets out a global framework to avoid dangerous climate change by limiting global warming to well below $2{ }^{\circ} \mathrm{C}$ and pursuing efforts to limit it to $1.5^{\circ} \mathrm{C}$ [3]. Furthermore, in 2018, the European Commission updated its long-term strategic vision to achieve a prosperous, modern, competitive, and climate-neutral economy by 2050 [4].

The future energy economy will likely be based on a wide range of alternative energy platforms (wind, water, sun, etc.) as well as biomass. Similarly, the production of chemicals will increasingly depend on biomass, particularly plant biomass [1]. The objective of the Paris Agreement to reduce greenhouse emissions by at least $42 \%$ by 2030 has significantly encouraged the use of biomass as a renewable source of energy, and forest residues such as bushes and aerial parts of trees, which play an important role in forest management, have been used mainly for fuel. However, the use of these bioresources to produce high-added-value products is becoming increasingly important in the context of 
sustainability and bioeconomy, as agroforestry biomass can be recovered in biorefineries with environmental, economic, and social benefits [5]. In addition, the use of forest residues in biorefineries could have a secondary environmental benefit. Forest residues remaining in forests after thinning or logging could pose a high fire risk because, without a developed market, it is often disposed of and burned in the field, contributing to air pollution [6].

One of the main driving economic factors for the production of renewable chemicals is feedstock availability, and scaling strategies must take this variable into account [7]. The potential of forest residues can be assessed in Spain with residues from olive tree pruning (OTP), pine (PN), and eucalyptus (ER) harvesting and thinning. The olive oil production industry has a significant importance in the Mediterranean countries of the European Union, especially in Spain, due to the large extension of olive growing area and the number and capacity of olive processing facilities. With a cultivated area of 2.5 Mha in 2019 [8], representing 24.4\% of world production, Spain is positioned as a leader in olive cultivation [9]. Olive cultivation generates a large amount of biomass residues from pruning $1.5 \mathrm{t} / \mathrm{ha} \mathrm{[10],} \mathrm{therefore,}$ the availability of OTP reaches 3.8 Mt/year in Spain. Olive residues have been studied for their use in biorefineries for the production of biofuels (ethanol) and bioproducts (xylitol and antioxidants) [11, 12]. Regarding pine and eucalyptus residues, Spain has a logging area of $18 \mathrm{Mha}$, of which the logging volume of pine is $524 \mathrm{Mm}^{3}$ while that of eucalyptus is $79 \mathrm{Mm}^{3}$. In 2018, according to the Spanish Ministry of Agriculture, pine and eucalyptus logging reached a volume of $10.4 \mathrm{Mm}^{3}$ and $7.8 \mathrm{Mm}^{3}$ [13]. These harvests generated an amount of pine and eucalyptus residues of $52 \mathrm{Mt} / \mathrm{year}$ $[14,15]$ and $0.7 \mathrm{Mt} /$ year [16, 17], respectively. Eucalyptus has been studied for bioenergy production (ethanol, Fischer-Tropsch fuels) [18-20] and value-added products such as xylitol [21] as well as pine bioenergy [20, 22, 23].

Biofuels, especially so-called second-generation advanced biofuels (lignocellulosic ethanol, Fischer-Tropsch fuels, lignocellulosic methanol-to-gasoline, lignocellulosic pyrolytic gasoline, etc.), generally cannot be produced in a profitable way at the current price of fossil gasoline and first-generation ethanol.

A promising approach to reduce biofuel production costs is to use so-called biofuel-driven biorefineries for the coproduction of both value-added products and biofuels from biomass resources in a very efficient integrated approach (similar to oil refineries). The added value of the coproducts makes it possible to produce fuels at costs that are market competitive [24]. In 2004, the U.S. Department of Energy (DOE) [25] listed 12 promising building blocks (BB) that could be produced via fermentative or chemical processes, revisited in 2010 by Bozell et al. [26]. A mix of some building blocks proposed by the US Department (DOE)
(2004) and Bozell et al. (2010) (ethanol, xylitol, sorbitol, succinic acid, glutamic acid, glucaric acid, levulinic acid, lactic acid, and itaconic acid) have been considered in this study to assess their feasibility of implementation in Spain. Therefore, the aim of this work is to provide a tool for the systematic evaluation of different routes for advanced biofuels production and biochemicals using forest residues as raw material.

The following is a description of the technologies considered, divided into thermochemical routes for the hydrogen and advanced biofuels production (pyrolysis gasoline, gasification-Fischer-Tropsch gasoline, gasification-MTG gasoline, gasification-mixed alcohols ethanol) and biochemi$\mathrm{cal} /$ chemical routes building blocks production (fermentative ethanol, xylitol, sorbitol and glutamic, glucaric, itaconic, succinic, lactic, and levulinic acids). All routes included in this work reach at least TRL 5-6, which implies the demonstration of the technology in a relevant environment, which is a major step towards demonstrating technological maturity.

Among the thermochemical routes studied are lignocellulosic fast pyrolysis and upgrading to gasoline. Pyrolysis is the controlled thermal decomposition of biomass at moderate temperatures, in the absence of oxygen, to produce liquid oil, gas, and charcoal (biochar). Conventional fast pyrolysis technologies for bio-oil for heat and power applications have already been commercialized; however, the upgrading has been less developed [27, 28]. Dutta et al. (2015) [29] reported a minimum selling price for fast pyrolysis gasoline of $1.36 \$ / \mathrm{kg}$, a $15 \%$ higher than the fossil-based gasoline price. Thilakaratne et al. (2014) [30], who proposed a mild catalytic pyrolysis biomass process to produce transport fuels, reach a minimum selling price of 1.44 \$/ $\mathrm{kg}, 20 \%$ higher than the fossil-based gasoline price, while Mohammed et al. (2019) [31] reported a minimum selling price of $2.13 \$ / \mathrm{kg}, 47 \%$ over fossil gasoline price. Another thermochemical route considered is gasification with Fischer-Tropsch synthesis, where gasification converts biomass feedstock into syngas, which is cleaned and conditioned; during Fischer-Tropsch (FT) synthesis, syngas is reacted over metallic catalysts to produce a mixture of long-chain hydrocarbons, which may then be upgraded via standard refinery processes. Both gasification and FT synthesis are well-established commercial processes when using fossil feedstocks; however, their use with biomass feedstocks is more limited [20, 27]. Trippe et al. (2013) [32], reached a wood residues Fischer-Tropsch gasoline production cost of $1.29 \$ / \mathrm{kg}$, close to the market conventional gasoline price. Gasification with mixed alcohols (MA) seeks gasification followed by methanol-to-gasoline production of ethanol and higher alcohol coproduct by conversion of lignocellulosic biomass to syngas via indirect gasification followed by gasto-liquid synthesis over a heterogeneous catalyst $[27,33]$. 
In gasification followed by methanol-to-gasoline (MTG), after syngas conversion to methanol, methanol is dehydrated over a catalyst to form dimethyl ether (DME), followed by further catalytic dehydration and hydrogenation reactions through light olefins to gasoline [27, 34]. Ruddy et al. (2011) [35] reported a MTG biomass gasoline production cost of $1.35 \$ / \mathrm{kg}$, similar to the current market gasoline price. In lignocellulosic hydrogen production, after gasification, and conditioning, the reforming, shift conversion and pressure swing adsorption (PSA) operations allow producing hydrogen [36, 37].

Regarding biochemical and chemical routes, lignocellulosic ethanol is both an advanced biofuel and a building block. First-generation ethanol is by far the largest biochemical produced today with more than $80 \%$ share of total production, and its production from sugarcane juice or corn grains is well established. Second-generation ethanol is expected to increase its contribution to the ethanol global market through the growth in the commercialization of lignocellulosic ethanol from inexpensive wastes, particularly because the European Union biofuel policies promote the progress of the generation of cellulose-based biofuels worldwide [38]. However, under the assumption of an ethanol yield of $250 \mathrm{l} / \mathrm{t}$ (with a feedstock price of $50 \$ / \mathrm{t}$ ), the estimated cost of lignocellulosic ethanol is $1.14 \$ / \mathrm{kg}$ [39], a $28 \%$ higher than market first-generation ethanol price $(0.823$ $\$ / \mathrm{kg}$ ) [40] suggesting limited profitability of $2 \mathrm{G}$ ethanol at this time. The recalcitrant nature of lignocellulosic biomass entails pretreatment processes to unlock the cell wall and make the structure porous, as well as changing or removing the structural and compositional impediments before its valorization and allowing the generation of second-generation sugars by catalytic or biocatalytic processes (acid catalysts, enzymes). These sugars are the backbone of biorefinery and are natural intermediates in biological as well as chemical transformation [41, 42]. Pretreatment is the second largest production cost after feedstock cost, and this will continue to be the case in future commercial facilities [39], so different pretreatments are evaluated: dilute acid (DA) [43], liquid hot water (LHW), AFEX [44, 45] and steam explosion (SE) [46, 47]. Steam explosion pretreatment is followed by simultaneous saccharification fermentation technology (SSF), while remaining pretreatments are followed by separate hydrolysis and fermentation (enzymatic hydrolysis (EH) and fermentation).

In the remaining sugar-platform building blocks, succinic acid is widely applied in food, medicine, surfactants, and biodegradable plastics. The traditional chemical synthesis of succinic acid has faced several problems, such as high production costs and serious environmental pollution problems. Therefore, researchers have focused on the use of lignocellulosic biomass by environmentally friendly biological methods [48]. Nieder-Heitmann et al. (2019) [49] investigated a multi-product biorefinery for the coproduction of bioenergy, PHB, and succinic acid from sugarcane bagasse, and Giuliano et al. (2016) applied an optimization model to address the biomass type effect (eucalyptus and olive residues and wheat straw) in the profitability of a biorefinery to co-producing ethanol, succinic, and levulinic acid [50]. As a chemical linker between biomass and petroleum processing, levulinic acid has become an ideal feedstock for the formation of liquid fuels, in addition to being used in herbicides, pharmaceuticals, flavoring agents, surfactants, etc. [51]. The first levulinic synthesis technology is biofine process levulinic is synthesized from biomass containing cellulose using a sulfuric acid catalyst with two reaction stages. The first stage is the cellulose reaction by HMF followed by the reaction of HMF to levulinic in the second stage [52]. Kapanji et al. (2021) [53] studied the sustainability of levulinic via biofine process and glucaric and sorbitol catalytic production (oxidation and hydrogenation, respectively) from sugarcane bagasse. Since no petrochemical feedstocks exist for sorbitol and glucaric acid, they have been produced conventionally from monomeric sugar, glucose, or starch precursors from the first-generation, edible feedstocks, so the development of its production from lignocellulosic biomass is of particular interest. Kapanji et al. (2019) [54] proposed sorbitol production from sugarcane bagasse and Thaore et al. (2020) [55] from corn stover. Another building block considered is glutamic acid, an amino acid with applications in the food and pharmaceutical industry. Although amino acids can be produced by protein and enzymatic hydrolysis, fermentation, and chemical synthesis, in recent years, they have been produced predominantly through fermentation using strains such as Corynebacterium and Brevibacterium. Özüdoğru et al. (2019) [56] studied its production from lignocellulosic biomass via dilute acid pretreatment and fermentation with the microorganism Brevibacterium divaricatum. Regarding xylitol, it has important applications in the food, odontological, and pharmaceutical industries, besides acting as a platform chemical for the synthesis of other high-value compounds, such as propylene glycol, glycerol, and polymers. The commercial demand for xylitol has been satisfied by the application of chemical synthesis. This process involves the thermochemical pretreatment of the lignocellulosic biomass to generate a xylose-rich hemicellulosic hydrolysate from which the xylose is further purified and then catalytically reduced to xylitol [57]. The chemical route is proposed by Özüdoğru et al. (2019)[56] to produce xylitol from sugarcane bagasse, although fermentative route, proposed, for instance, by Susmozas et al. [12] from olive tree pruning is gaining attention due to the interest to be an eco-friendly process. The potential of itaconic acid produced by fermentation has been investigated and demonstrated by several authors as a renewable alternative to classic monomers in the petrochemical industry, such as acrylic and methacrylic 
acids [58]. Its lignocellulosic production has been studied by Magalhães et al. (2020) [58] from broths rich in xylose and using bleached cellulose pulp from Eucalyptus by Kerssemakers et al. (2020) [59]. Finally, lactic acid is the most frequently occurring carboxylic acid in nature. Lactic acid is used worldwide for applications in food, pharmaceuticals, industrial use, and polymers. The growth of polylactic acid polymer production is expected to drive the growth of lactic acid consumption [60]. Currently, lactic acid is produced predominantly from the fermentation of first-generation sugars. Li et al. (2021) [61] and Liu et al. (2015) [62] proposed its production from corn stover, lignocellulose-derived lactic acid, and its derivatives may accelerate the phasing out of emission-intensive fossil-based plastics.

The article is structured as follows: (i) Sect. 2 presents the problem to be solved and the parameters defining the feedstock-technology-product superstructure, (ii) Sect. 3 describes the mathematical linear programming model and solution strategies, and (iii) Sect. 4 presents the main results together with the discussion and limitations of the study.

\section{Problem statement}

Numerous mathematical optimization approaches have been developed for the optimal synthesis and design of biorefineries. Due to a large number of possible pathways, the synthesis and design problems of an integrated biorefinery are highly complex problems. Kokossis and Yang (2010) [63] proposed a layered approach to the problem emphasizing the pivotal role of process system technologies. Pham and El-Halwagi (2012) [64] proposed a methodology for the synthesis and design of biorefineries that consists of a threestep approach. In the first step (forward step), all possible intermediate products and their conversion technologies are identified for different biomass. In the second step (backward approach), for a final product, the intermediate compounds and their corresponding technologies are determined. The next step corresponds to the matching of two intermediate compounds obtained in the forward and backward steps. Pham and El-Halwagi (2012) applied their study to the production of the most profitable fuel-grade alcohol pathway from lignocellulosic biomass. Murillo-Alvarado et al. (2013) [65], following the Pham and El-Halwagi approach, found that bioethanol, biodiesel, and biohydrogen usually appeared as products, while sugar cane, jatropha, and microalgae appear as feedstocks in the optimal pathways. König et al. (2019) [66] applied a superstructure approach to identify the optimal routes (biofuels and/or e-fuels) to meet the energy demand from residual lignocellulosic biomass and waste vegetable oil. Recently, You et al. (2021) [67] proposed a new optimization model to simultaneously identify the optimal process configuration of a bioethanol production plant and the optimal bioethanol supply network. Although the studies mentioned above are of undoubted interest, they only considered the optimization of biofuels and not of other value-added products.

The existing literature for the production of bioenergy and value-added products based on mathematical optimization includes Cheali et al. (2015) [68] and Álvarez del CastilloRomo et al. (2018) [69]. Cheali et al. (2015) considered thermal and biochemical platforms for bioethanol production and its value-added derivatives from corn stover and poplar wood in a sustainability assessment method used as an evaluation tool. Álvarez del Castillo-Romo et al. (2018) studied a wider product portfolio from agave bagasse. Their study focused on the way of integrating social, environmental, and economic aspects (socio-eco-efficient aspects), which is interesting from the point of view of sustainability. Giuliano et al. (2016) [70] applied an optimization MILP model on a process superstructure in multi-product lignocellulosic biorefinery (levulinic acid, succinic acid, and ethanol) to maximize an economic objective function, but feedstock and energy requirements were not considered.

Different researches have focused on the analysis and design of bioproducts supply chains. Many studies have investigated the optimization of the supply chain considering location selection [71-73]. Other models consider timedependent parameters such as demand. This issue can be addressed with multi-period optimization $[74,75]$. On the other hand, if the sustainability of the biorefinery is analyzed, the optimization should also consider environmental and social criteria $[69,76-79]$ in addition to the economic ones, which can be done by multi-objective optimization. The aim of this work is to provide a steady-state snapshot of the potential situation of biorefineries in Spain for the production of biofuels and value-added products. Furthermore, the decision-making choice of feedstock-technologyproduct under economic and energy requirement criteria is facilitated. For these reasons, the aforementioned approaches have not been applied here, although they are considered of great interest.

Due to the many possible combinations of feedstock and conversion technologies as viable pathways to manufacture advanced biofuels and bio-based building blocks, it is important to establish a methodology to support decisionmakers to identify optimal processing routes taking into account economics, resource availability, and sustainability [80]. Feedstock availability and price are among the main factors in the successful scale-up of a biorefinery, the right choice of feedstock-process-product trinomial is, therefore, a critical decision [7]. The development of a superstructure that simultaneously considers all three aspects can therefore become a useful decision-making tool. To solve the problem of identifying the optimal solutions, we apply in this work a similar methodology based on network optimization models 
as proposed by Kim et al. (2013) [81] and Calvo-Serrano et al. (2019) [78]. Kim et al. (2013) focus their method on biomass-to-fuel conversion technologies, and Calvo-Serrano et al. (2019), moreover to energy and chemical products, present a life-cycle approach. They examined biomass-toproduct strategies by decomposing the whole process into intermediate subprocesses and thereby identifying the most convenient mass flux distribution [82]. The superstructure is made up of nodes (feedstocks, technologies, intermediates, and final products) linked by flow arcs (purchased feedstocks, consumption, and generation of materials for each technology, total final product sales). The developed superstructure of this study consists of three feedstocks (pine, eucalyptus, and olive residues), 183 technologies (thermochemical and biochemical), 150 intermediates, and 33 final products from each feedstock.

Following the methodology of Kim et al. (2013) [81], the technological blocks of the superstructure include several single operations. For example, enzymatic hydrolysis may comprise hydrolysis, hydrolysate detoxification, and in situ enzyme production. Similarly, so-called separation technologies comprise in addition to purification and separation operations, water treatment, and waste combustion for energy integration if these aspects are evaluated in the process design literature. Moreover, when different feedstocks are used in the same pathway, every matched feedstock technology should be considered different technologies, namely, pine dilute acid ethanol is a technology, and eucalyptus dilute acid ethanol is another new one.

This management tool compares, using economic and energy criteria, different feedstocks through different routes to produce a portfolio of products. The solution is an optimal network capable of meeting portfolio product demand. To compare the different strategies or routes in a level playing field, the processing capacity of the different strategies should be equal. Kim et al. proposed $2000 \mathrm{t} / \mathrm{d}$, we maintain this value because, following a literature review, it was found that the most suitable plant size in a biorefinery to reduce the total product cost is between 2000 and $4000 \mathrm{t} / \mathrm{d}$ [39, 83, 84].

Forest residues evaluated (pine, eucalyptus, and olive residues) are defined by their availability $\left(\beta_{\mathrm{i}}, \mathrm{kg} /\right.$ year $)$ and cost price $\left(P C_{\mathrm{i}}, \$ / \mathrm{kg}\right)$ that includes harvesting cost and transport to biorefinery $(100 \mathrm{~km})$ while final products are defined by demand $\left(D_{\mathrm{i}}, \mathrm{kg} / \mathrm{year}\right)$ and sale price $\left(P C_{\mathrm{i}}, \$ / \mathrm{kg}\right)$ (forest residues availability and price data can be found in Supplementary Material Table 3). Each technology block is defined by an economic parameter, called unit technology cost $\left(T C_{\mathrm{i}}\right.$, $\$ / \mathrm{kg}$ main steam input), an energy parameter, unit energy requirement $\left(T E_{\mathrm{i}}, \mathrm{Wh} / \mathrm{kg}\right.$ main steam input), and a technical parameter, the mass ratio $\left(m b_{\mathrm{i}}, \mathrm{kg}\right.$ of product stream $/ \mathrm{kg}$ of mainstream input). The mass ratio is negative for technology inputs (material stream consumption) and positive for technology outputs (material stream production). Besides, $m b_{\mathrm{i}}$ can be higher than 1 , this could occur, for instance, in pretreatment and fermentation technologies because in product streams are included utility input streams such as water. $T C_{\mathrm{i}}$ considers a capital change factor of 0.1175 at an interest rate of $10 \%$ and 20 years of plant lifetime and includes fixed operating cost (labor charges, maintenance, administration cost, and taxes), auxiliary inputs (chemicals and enzymes), and utilities but not feedstock and energy cost. To conclude, final products are characterized by their demand $\left(\mathbf{D}_{\mathrm{i}}, \mathrm{kg} /\right.$ year) and market price $\left(P C_{\mathrm{i}}, \$ / \mathrm{kg}\right)$ (final product demand and market price data can be found in Supplementary Material Table 3).

These parameters define every strategy that builds the superstructure, but although routes' TRL is upper 5 , not always every forest feedstock technology data is available in the literature. In this case, when all process reactions are known, mass balances shall be completely recalculated for forest feedstock when not, Kim et al.[81] proposed estimation for new technologies shall be applied. This estimation uses the conversion coefficients of a known feedstock technology to calculate new technology yield (forest residues composition in Supplementary Material Table 1). For instance, we know cellulose to glucose yield in a known technology 1 , so we apply this yield to cellulose-glucose conversion in the new-feedstock technology 2. Regarding economic data (capital, fixed, and operating cost), it is assumed that they are proportional to the new technology/ known technology mass ratio. We use a power-law expression to estimate these parameters (Eq. 1)

$C_{\mathrm{NEW}}=C_{\mathrm{KNOWN}}\left(R_{\mathrm{NEW}} / R_{\mathrm{KNOWN}}\right)^{0.67}$

where $C_{\text {KNOwN }}$ are economic data in the known technology, $R_{\mathrm{NEW}}$ is the main input stream in new technology, and $R_{\mathrm{KNOWN}}$ is the main input stream in known technology.

The superstructure model developed for this study is shown in Fig. 1. The list of all technologies and economic, energy, and technical parameters that define each technology is tabulated in Table 2 in Supplementary Material.

\section{Model formulation and solution strategy}

The model consists of two sets, compounds, and technologies, defined by several parameters or data inputs and three nonnegative continuous variables or model answers that define the optimal routes solution:

\subsection{Sets}

(i) A set of compounds $i \in I$ : feedstocks $\left(I^{\mathrm{F}}\right)$, intermediates $\left(I^{\mathrm{I}}\right)$, and final products $\left(I^{\mathrm{P}}\right)$. Feedstock/final 
Fig. 1 Simplified feedstocktechnologies-products superstructure. Feedstock: PN, pinus residues; ER, eucalyptus residues OTP, olive tree pruning. Technologies: LHW, liquid hot water, AFEX: SE, steam explosion; DA, diluted acid; SSF, simultaneous saccharification and fermentation; Cat MA, catalytic conversion mixed alcohols; MTG, methanol to gasoline; PSA, pressure swing adsorption; Cat Hidrog, catalitic hydrogenation; Cat Oxig, catalitic oxigenation; Gas + Fisch, gasification and Fischer-Tropsch; BIOFINE, biofine process, separation

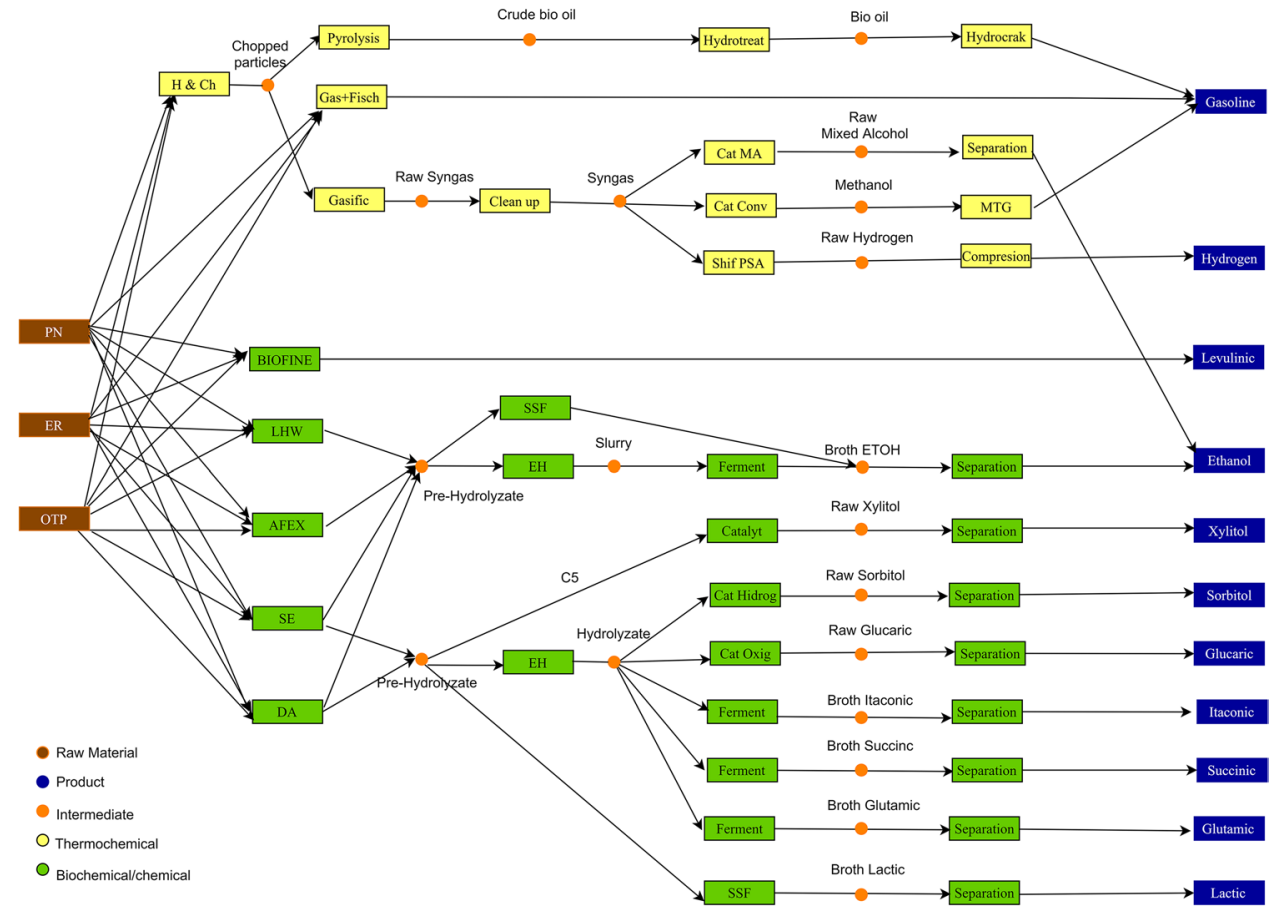

products are characterized by purchase/selling price parameters $\left(P C_{\mathrm{i}} \neq 0 \forall \mathrm{i} I^{F}, I^{P}\right.$ and $P C_{i}=0 \forall \mathrm{i} \in I^{\mathrm{I}}$ in $\$ / \mathrm{kg})$ and feedstock availability $\left(\beta_{i} \forall \mathrm{i} \in I^{\mathrm{F}}\right.$ and $\beta_{i}=0$ $\forall i \in I^{\mathrm{I}}, I^{\mathrm{P}}$ in $\mathrm{kg} /$ year $)$ and final products demand $\left(D_{i}\right.$ $\forall i \in I^{\mathrm{P}}$ and $D_{i}=0 \forall i \in I^{\mathrm{F}}, I^{\mathrm{I}}$ in $\mathrm{kg} /$ year).

(ii) A set of technologies $j$ : Each technology is both consumer and producer of compounds, so we set two subsets $J^{\mathrm{IN}}$ and $J^{\mathrm{OUT}}$. Technologies are characterized by unit technology cost $\left(T C_{j}, \$ / \mathrm{kg}\right.$ main input in $\left.j\right)$, unit energy requirement $\left(T E_{j}, \mathrm{Wh} / \mathrm{kg}\right.$ main input in $j$ ), and mass ratio $\left(m b_{i j}, \mathrm{~kg}\right.$ of output stream of $i / \mathrm{kg}$ of main input in $j$ ).

\subsection{Variables}

(iii) $X_{j}$ process activity flow $(\mathrm{kg}$ ) or the amount of raw material that needs to be consumed in technology $j$.

(iv) $P_{i}$ amount of feedstock purchased $(\mathrm{kg}), i \in I^{F}$.

(v) $S_{i}$ amount of product sold $(\mathrm{kg}), i \in I^{P}$.

The mass balance constrain is defined by Eq. 2. For any compound $i$ in the model, the amount of component purchased $\left(P_{i}\right)$ plus the amount produced must be equal to the amount sold $\left(S_{i}\right)$ plus the amount consumed.

$P_{i}+\sum_{j \in J^{\mathrm{OUT}}} m b_{i j} X_{i}=S_{i}+\sum_{j \in J \mathbb{N}} m b_{i j} X_{i} \forall i$

Sold compounds should satisfy the demand $\left(D_{i}\right)$ for all products $i \in I^{P}$ as represented in Eq. 3 .
$\left.S_{i} \geq D_{i} \forall_{i} \in I^{P}\right)$

Feedstock purchased is limited by feedstocks availability $\left(\beta_{i}\right)$, specific to each forest residue evaluated and is enforced by Eq. 4 .

$P_{i} \leq \beta_{i} \forall i \in I^{F}$

In this mathematical model, the only feedstock can be purchased, and only final products can be sold. Equations 5 and 6 are included to enforce this constraint.

$P_{i}=0 \forall i \in I^{I}$

$\left.S_{i}=0 \forall i \in I^{F}, I^{I}\right)$

This mathematical model allows different questions to be answered depending on the objective function. To find the optimal biorefineries network with minimum production cost $\left(E C_{j}\right.$ is energy purchased cost, $\left.\$ / \mathrm{Wh}\right)$, Eq. 7 should be used. If we want to know the most profitable network, we use Eq. 8, and to know the lowest energy consumption network, we use Eq. 9.

$\operatorname{minTot} C=\sum_{i \in I^{F}} P C_{i} P_{i}+\sum_{j} X_{j}\left(T C_{j}+T E_{j} E C_{j}\right)$

maxProf it $\left.=\sum_{i \in I^{P}} P C_{i} S_{i}-\sum_{i \in I^{F}} P C_{i} P_{i}-\sum_{j} X_{j}\left(T C_{j}+T E_{j} E C_{j}\right)\right)$ 
$\operatorname{minTotERQ}=\sum_{j} X_{j} T E_{j}$

In addition, we can know the unit production cost (UPC, $\$$ cost $/ \mathrm{kg}$ product), the unit profit (UP, $\$$ profit $/ \mathrm{kg}$ product), and the unit energy consumption (UER, Wh consumed $/ \mathrm{kg}$ product) by running the corresponding objective function for the product in question with a demand equal to one and set zero to remaining products.

As for the solution strategy, we apply the $\mathcal{E}$-constraint method to draw a Pareto frontier. The extreme solutions minimum production cost and minimum energy requirement are calculated, and for different values of $\varepsilon$ other solutions are calculated iteratively. All points in the Pareto frontier are optimal solutions, each one with a specific value for the two objective functions so that improving one implies worsening the other.

Furthermore, we can break down each route contribution in the Pareto solutions in terms of minimum cost and energy consumption. For each Pareto solution, we know how much final product is produced per route $\left(S_{i}\right)$, and since we also know the unit production cost, unit energy consumption, and unit profit (UPC, UER, and UP, respectively), the contribution of each route to the optimal solutions can be known.

\section{Results and discussion}

For the biochemicals and biofuels production in Spain, a systematic evaluation of different woody residues feedstock and technologies was carried out with the proposed linear programming approach. The optimization model was implemented in the General Algebraic Modeling System (GAMS) software V025.0.0 and solved using CPLEX 12.8.0.0 solver. Every Pareto solution takes $0.14 \mathrm{~s}$.

\subsection{Individual analysis of available technologies: spotlight on building blocks}

Individual analysis of the market position of each of the different products in the portfolio facilitates decision-making. Hence, we evaluate the commercial characteristics of the target products of this study focusing on building blocks.

Figure 2a illustrates a breakdown of UP versus unit energy requirements (UER) for the products considered (final products UP and UER in Supplementary Material Table 4). We can see a better economic-energy performance of building blocks than fuels. According to the data in the articles consulted, only lactic acid production, from the three feedstocks selected, is profitable in the current market conditions. For instance, eucalyptus lactic unit profit is $0.259 \$ / \mathrm{kg}$ while the unit profits from the remaining building block are negative. However, eucalyptus residue lactic's unit energy consumption is almost nine times higher than eucalyptus residue succinic one $(29,520.114$ and $3399.604 \mathrm{Wh} / \mathrm{kg}$, respectively) and three times eucalyptus residues levulinic. The succinic production route is less energy demanding because $28 \%$ of the input feedstock is directed to a CHP unit that provides part of the energy needed for the process, whereas in the lactic route only the process waste is dedicated to energy. In particular, eucalyptus succinic and levulinic production is close to the break-even point or zero benefits with lower energy requirements. On the contrary, pine residue xylitol has the worst economic-energy behavior of all products. This is due to the fact, that xylitol production is based on the catalytic conversion of xylose fraction of lignocellulosics biomass and pine residues has only $7 \%$ of xylan in its composition versus $16 \%$ in eucalyptus and olive residues. Regarding bioethanol technologies, two routes should be highlighted, dilute acid and steam explosion from eucalyptus residues. Eucalyptus and pine dilute acid route (first reactor $100{ }^{\circ} \mathrm{C}, 10 \mathrm{~min}$, and second reactor $158^{\circ} \mathrm{C}, 5 \mathrm{~min}$, ammonia conditioning $\mathrm{pH} 1$ to 5 , water/dry biomass ratio 4:1) is close to zero profit. Its energy consumption is $35 \%$ grdeater than pine steam explosion $\left(215^{\circ} \mathrm{C}, 5 \mathrm{~min}\right)$; while steam explosion achieves a profit five times minor. These results are similar to those presented by Kumar et al. (2011) [85], where the energy requirements of cellulosic ethanol production by dilute acid $\left(180{ }^{\circ} \mathrm{C}, 15 \mathrm{~min}\right.$, solid loading $\left.15 \%\right)$ are $30 \%$ higher than steam explosion ethanol $\left(180^{\circ} \mathrm{C}, 15 \mathrm{~min}\right.$, solid loading 20\%). Baral et al. (2017) [86], in their study, also reach a higher energy requirement in the dilute acid pretreatment $\left(160{ }^{\circ} \mathrm{C}, 20 \mathrm{~min}\right)$, specifically $20 \%$ more, than steam explosion pretreatment $\left(200{ }^{\circ} \mathrm{C}, 5 \mathrm{~min}\right)$. According to the studies consulted, AFEX ethanol $\left(150{ }^{\circ} \mathrm{C}, 30 \mathrm{~min}\right.$, water/ dry biomass ratio $0.81: 1$, ammonia/dry biomass ratio $1.52: 1$ ) from olive residues shows the worst performance with a benefit five times lower than dilute acid from eucalyptus and an energy requirement three times higher. These results are similar to the ones shown by Liu et al. (2017) [87], in which the energy requirement of AFEX is twice that dilute acid one. This is due primarily to the lower sugar yields from consulted AFEX studies, which means lower profits and higher unit energy requirements. Concerning thermochemical pathways, according to data in consulted literature, gasoline produced by pyrolysis from olive residues shows a good economic and energetic performance while MTG from pine reaches a major profit but with twice energy consumption. The calculations show that MTG capital costs are 50\% lower than pyrolysis, but the MTG yield is also 50\% lower, so more energy consumption is needed to produce the same volume of gasoline. On the contrary, gasoline produced in the Fischer-Tropsch route from eucalyptus shows the best energy performance but the poorest thermochemical profit.

To get further insights about building blocks, Fig. $2 \mathrm{~b}$ shows the feedstock price to break-even point (FBP), i.e., 
Fig. 2 (a) Breakdown of unit profit versus unit energy requirement for products considered. b Break-even feedstock price for building blocks and product price change effects. c Breakdown of profit versus demand for all products considered

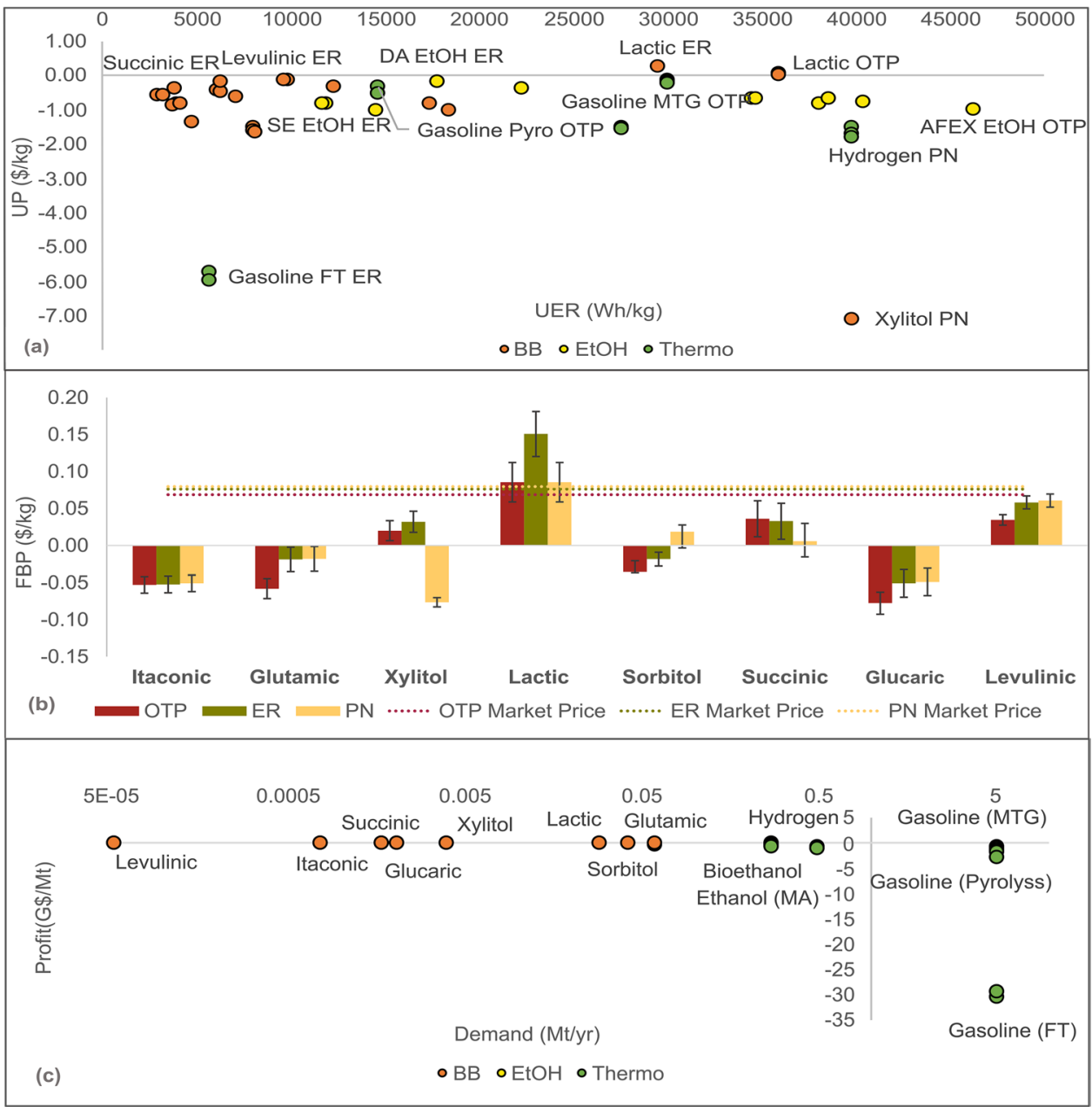

the raw material price for which building blocks production has zero profit (FBP data in Supplementary Material Table 4). Therefore, in Fig. 2b, routes with FBP positive are potentially profitable if feedstock prices change. If a route is already profitable, the break-even price represents the maximum price the commodity can reach to remain in the positive profit zone. If the route is not profitable, the break-even price is the price at which feedstock must fall and from which the profit becomes positive. Lactic acid production from the three forest residues is the only profitable route, so olive, eucalyptus, and pine residues could increase their price at $25 \%, 82 \%$, and $8 \%$ over the current market raw material price. Although three-residue levulinic routes are not profitable, $50 \%$ olive, $25 \%$ eucalyptus, and pine price declines would set them in threshold zero profit. For xylitol, succinic, and sorbitol, their performance depends on their raw material, only xylitol and succinic from olive and eucalyptus and pine sorbitol could be profitable. This figure also discusses the effect of product price change in FBP and building blocks routes profitability since, as explained above, if a route is profitable, its FBP will be above its market price line and if not, below (but below with positive FBP is potentially profitable). Changes of $\pm 7.3 \%$ in the price of the products are considered (Producer Price Index in October 2021, percentage changes in the intermediate demand index for energy goods, seasonally adjusted) [88]. It can be observed that for increases in products price (top bar whisker), there are no changes in the route's profitability, except for eucalyptus and pine glutamic acid, which approaches the break-even point. For decreases (bottom bar whisker) in products price, olive and pine lactic lose their profitability at current feedstock market price as well as pine succinic.

Building blocks (including ethanol) show good economic and energy performance, but their demand in Spain is much lower than advanced biofuels (pyrolysis gasoline, MTG gasoline, Fischer-Tropsch fuels) or hydrogen for industrial use and future transport applications. Figure 2c illustrates Spanish building block demand versus total production profit. For instance, Spanish lactic demand is 175 times lower than gasoline and levulinic demand is 9000 times lower than hydrogen demand. The main driver for the development and implementation of the biorefinery process today is the transportation sector. Therefore, to evaluate the use 
of forestry residues in Spain, it is necessary to consider the group of biorefineries capable of satisfying the demand for all these products.

\subsection{Optimal biorefinery solutions: Spanish scenario}

The proposed methodology for the correct choice of feedstock-process-final product is applied in the Spanish scenario. The availability of forest residues and the demand for products in Spain enforce the optimization of the model.

Figure 3 represents the optimal biorefinery network for minimum production cost (P1). Optimal routes in gasoline production are pine residues pyrolysis $(58 \%)$, pine residue MTG (30\%), and olive residue pyrolysis $(12 \%)$, in ethanol production, are pine dilute acid (53\%) and eucalyptus dilute acid (47\%). Regarding hydrogen, the optimal route is its production from pine residues. The remaining building blocks, levulinic, glucaric, itaconic, and glutamic are totally produced from pine residues, xylitol, and lactic from eucalyptus waste, and succinic from olive tree pruning. Data for Fig. 3 can be found in Supplementary Material Table 5.

Figure 4 illustrates the optimal biorefinery network for minimum energy consumption (P20). Optimal routes for gasoline production are pine residues pyrolysis (94\%) and pine Fischer-Tropsch (6\%), hydrogen production is distributed as $69 \%$ from pine residues, $29 \%$ from olive waste, and $2 \%$ from eucalyptus. Regarding ethanol, it is produced from the pine steam explosion route. Glucaric and itaconic acids are produced from eucalyptus residues, while the remaining building blocks follow the same routes that minimum cost solution. Data for Fig. 4 can be found in Supplementary Material Table 5.

Figure 5a shows the Pareto frontier between minimum cost production and minimum energy requirement in the proposed optimization model. Every point along the Pareto curve depicts the optimal trade-off of both objectives. Each point represents a set of routes capable of satisfying the demand for all products considered with the amount of lignocellulosic residues available for a specific cost-energy consumption relation. The minimum cost solution corresponds to the P1 solution and the minimum energy requirement to the P20 solution. P1 solution reaches a total cost value of $11.285 \mathrm{G} \$$ with an energy consumption of 125,060 GWh while in P20, energy requirement could be reduced $23 \%$ but with a cost increase up to $18 \%$. However, the minimum cost solution supposes a cost increase of $32 \%$ over the market-price network solution, indicating that the minimum cost route network is economically inefficient. Figure $5 \mathrm{~b}$ illustrates the biomass feedstock contribution toward the satisfaction of products demand. Biomass residues are fully consumed in P1 and P20 solutions, but in the remaining optimal solutions, pine residues are not completely consumed. In P1, $97 \%$ of pine residues and $99 \%$ of olive residues are used in thermochemical routes, while $74 \%$ of eucalyptus residues are spent in ethanol production and the remaining in other building blocks. In P20, 93\% of pine residues are used in thermal processes and $5 \%$ in the ethanol route, so $40 \%$ of eucalyptus residues are used in hydrogen production and $60 \%$ in building blocks. Feedstocks spent in the process can be found in Supplementary Material Table 6 and Table 7.
Fig. 3 Simplified biomass process network for minimum cost solution (P1)

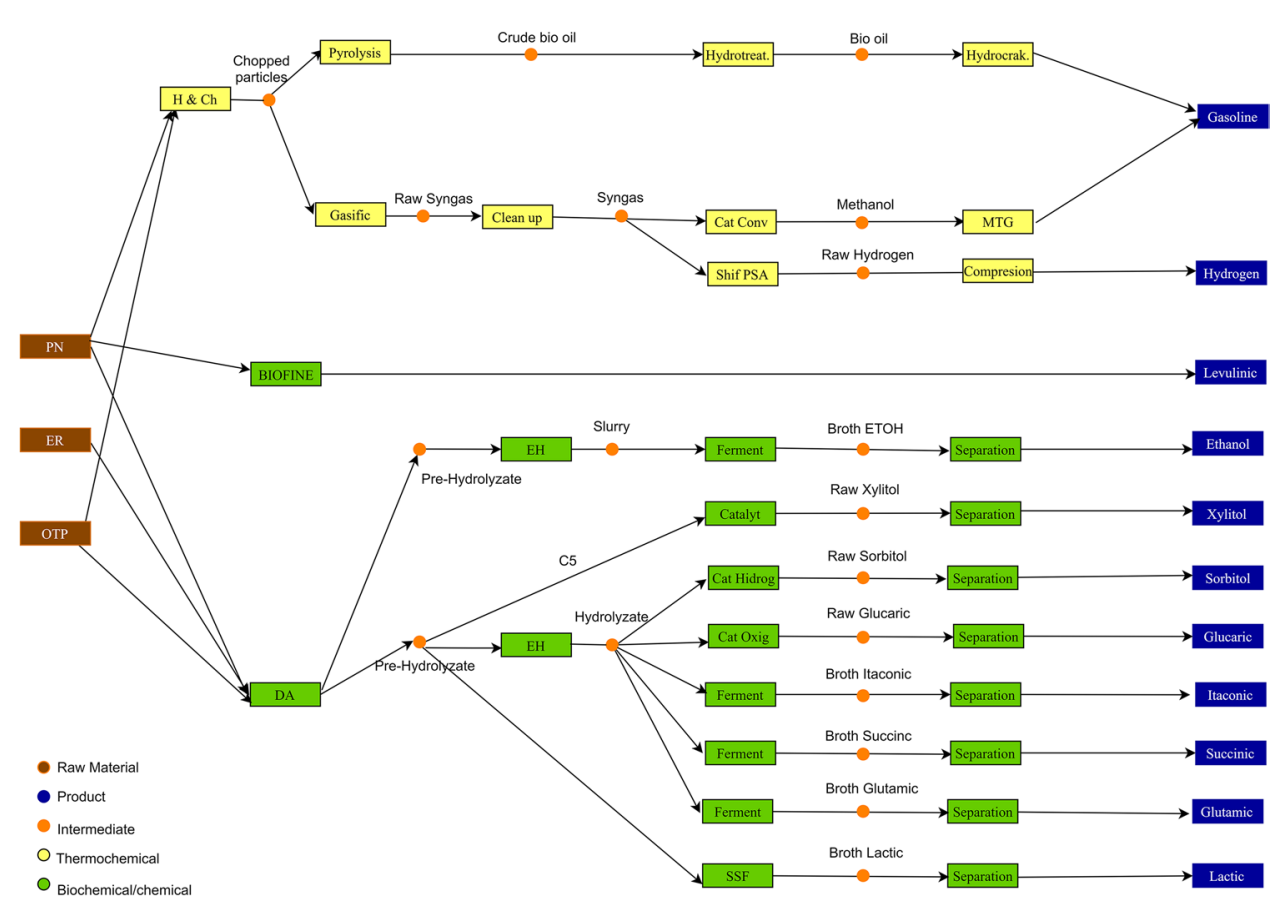


Fig. 4 Simplified biomass process network for minimum energy requirement solution (P20)

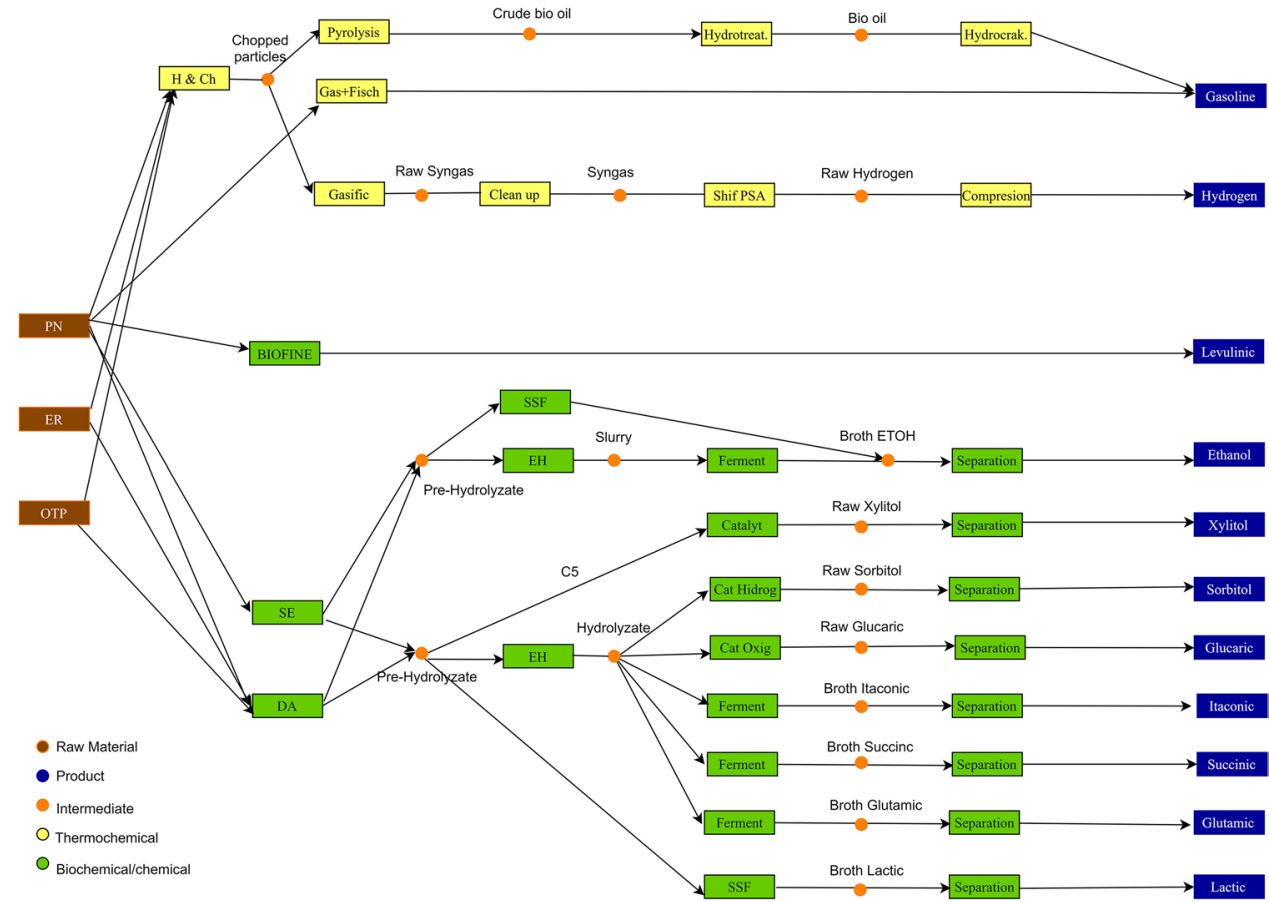

Figures $5 \mathrm{c}$ and $\mathrm{d}$ show a technological transition in which pine MTG weight decreases from P1 to P13 while pine pyrolysis' weight increases, moreover, pine Fischer-Tropsch technology is entered from P15. The main technology energy consumption and cost drivers in P1 solution are pine hydrogen, MTG, and pyrolysis $(16 \%$, $38 \%$, and $36 \%$ in energy and $19 \%, 22 \%$, and $45 \%$ in cost, respectively) and olive pyrolysis (7\% in energy and $9 \%$ in cost). While in the P20 solution, these drivers are pine hydrogen, pyrolysis, and Fischer-Tropsch (14\%, 73\%, and $1.7 \%$ in energy and $11 \%, 62 \%$, and $16 \%$ in cost). The main reason for this technological transition is that pine pyrolysis and Fischer-Tropsch UER is twice and five times lower than pine MTG, although pyrolysis UPC is $8 \%$ higher and Fisher Tropsch cost is five times MTG one. Moreover, other technology changes can be observed. Ethanol demand is satisfied in P1, as discussed in Fig. 3, by eucalyptus and pine residues dilute acid, while in P20, ethanol is produced via steam explosion from pine residues. Production via steam explosion provides $34 \%$ energy savings per kilogram of ethanol at the expense of increasing the cost by $62 \%$. Regarding other building blocks, sorbitol, itaconic, and glucaric acid are produced from pine residue in P1 whereas, in P20, they are produced from eucalyptus residues. This feedstock change results in a decrease of $1 \%, 2 \%$, and $12 \%$ energy consumption per kilogram of product and a steady cost (increase cost $4 \%, 1 \%$, and $0.3 \%$ per kilogram, respectively). As building blocks demands are much lower than those of advanced biofuels and hydrogen, their contribution in terms of energy requirement and cost to Pareto optimal solutions are not relevant. Data for Fig. 5 can be found in Supplementary Material Tables 4 and 5 .

Figure 5a-d illustrates the optimal biorefinery network limited by raw material availability, while Fig. 6a-d shows the infinite feedstock network and, therefore, the optimal set of routes from a technical perspective. In this way, feedstock availability influence in the selection of technologies could be evaluated. Figure $6 \mathrm{~b}$ depicts the biomass contribution to every optimal network. From P1 to P13 solution, olive residues are the major raw material (97 in P1\%) due to their market price being $16 \%$ lower than pine residues, from $\mathrm{P} 14$ pine residues contribution increases (38\% in $\mathrm{P} 14$ to $92 \%$ in $\mathrm{P} 20$ ). This pine growth is due to the entry of pine Fischer-Tropsch in the set of optimal technologies.

Figures $6 \mathrm{c}$ and d show energy requirement and cost contribution breakdown for infinite feedstock availability. As in the limited feedstock case, a technology transition from MTG to pyrolysis appears from P2 to P13 but with olive residues as feedstock and again from $\mathrm{P} 13$ to P20 pine Fischer-Tropsch enters in optimal network solutions. Therefore, no changes happen from the technical approach, but there are changes in a term of which is the optimal feedstock for each technology. No feedstock changes occur in Fischer-Tropsh route because pine Fischer-Tropsch yield is higher than olive and eucalyptus one and so energy requirements and cost are lower. Data for Fig. 6 can be found in Supplementary Material Tables 4 and 8 . 
Fig. 5 (a) Pareto curve for optimal values considering limited feedstock availability. b Feedstock contribution in Pareto solutions. c Breakdown of energy requirement contribution by technology in Pareto solutions. d Breakdown of cost contribution by technology in Pareto solutions

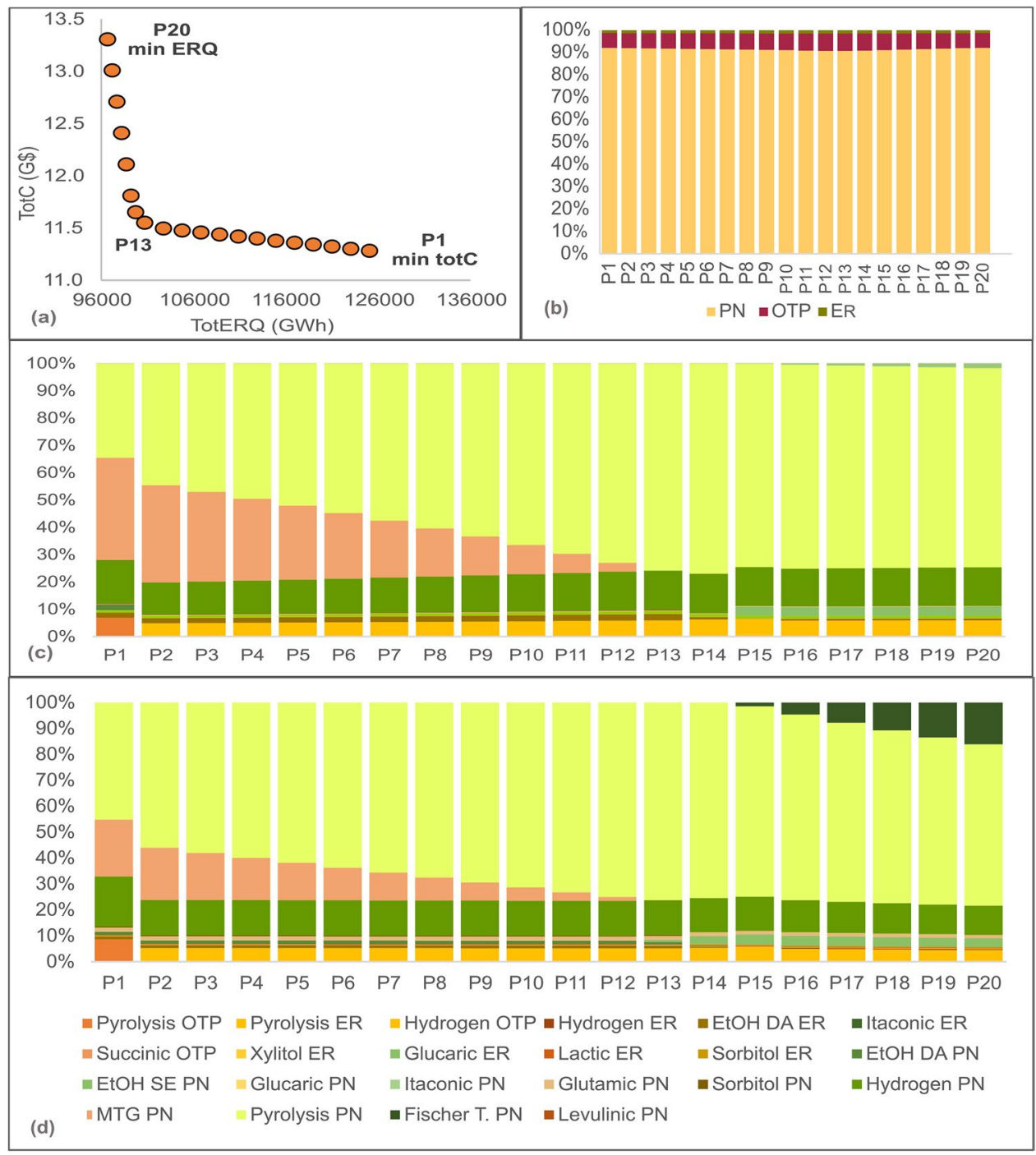

\subsection{Optimal biorefinery solutions for building blocks (including ethanol) in Spain}

The current oil price could act as a barrier to the viability of advanced thermochemical biofuels in gasoline production (MTG, pyrolysis, and Fischer-Tropsch), which also have the lowest TRL in studied routes, so it is interesting to asset the optimal routes that can meet the demand for BB in Spain (including ethanol).

Figure 7a shows the Pareto frontier for building blocks production in the Spanish scenario with limited feedstock availability. Again, the P1 point illustrates the minimum cost biorefinery network solution and P20 minimum energy requirement network. Minimum cost network consumes 38\% more energy than P20 solution but with a decreased cost of about $23 \%$. Regarding biomass contribution to meeting demand, Fig. $7 \mathrm{~b}$ shows that the contribution of pine residues is $65 \%$, while eucalyptus residues account for $34 \%$ in minor cost solutions. The contribution of pine increases to $89 \%$ in the lowest energy solution. Olive tree residues' contribution is small $(1 \%)$ compared to the other residues. Their composition has $25 \%$ less cellulose than pine and eucalyptus, so raw material and energy costs increase to meet demand, and although their prices are $12 \%$ lower, this does not balance the cost. Moreover, pine and olive residues are not fully consumed, but eucalyptus is, from solution P1 to P17.

Figures $7 \mathrm{c}$ and $\mathrm{d}$ illustrate energy requirement and cost contribution breakdown in the group of biorefineries that could meet Spanish building block demand. Again, the transition from dilute acid ethanol technology (47\% eucalyptus, $53 \%$ pine in $\mathrm{P} 1$ ) to steam explosion pine ethanol takes place. Every building block, except sorbitol and glucaric, is produced in all optimal network solutions by the same route as in limited availability cases, without any feedstock change. Lactic, itaconic, and xylitol are produced from eucalyptus residues, succinic from olive and glutamic, and levulinic from pine. Glucaric and sorbitol change pine to eucalyptus. In Fig. 7d, it could be observed that ethanol and glutamic 
Fig. 6 (a) Pareto curve for optimal values considering infinite feedstock availability. b Feedstock contribution in Pareto solutions. c Breakdown of energy requirement contribution by technology in Pareto solutions. d Breakdown of cost contribution by technology in Pareto solutions

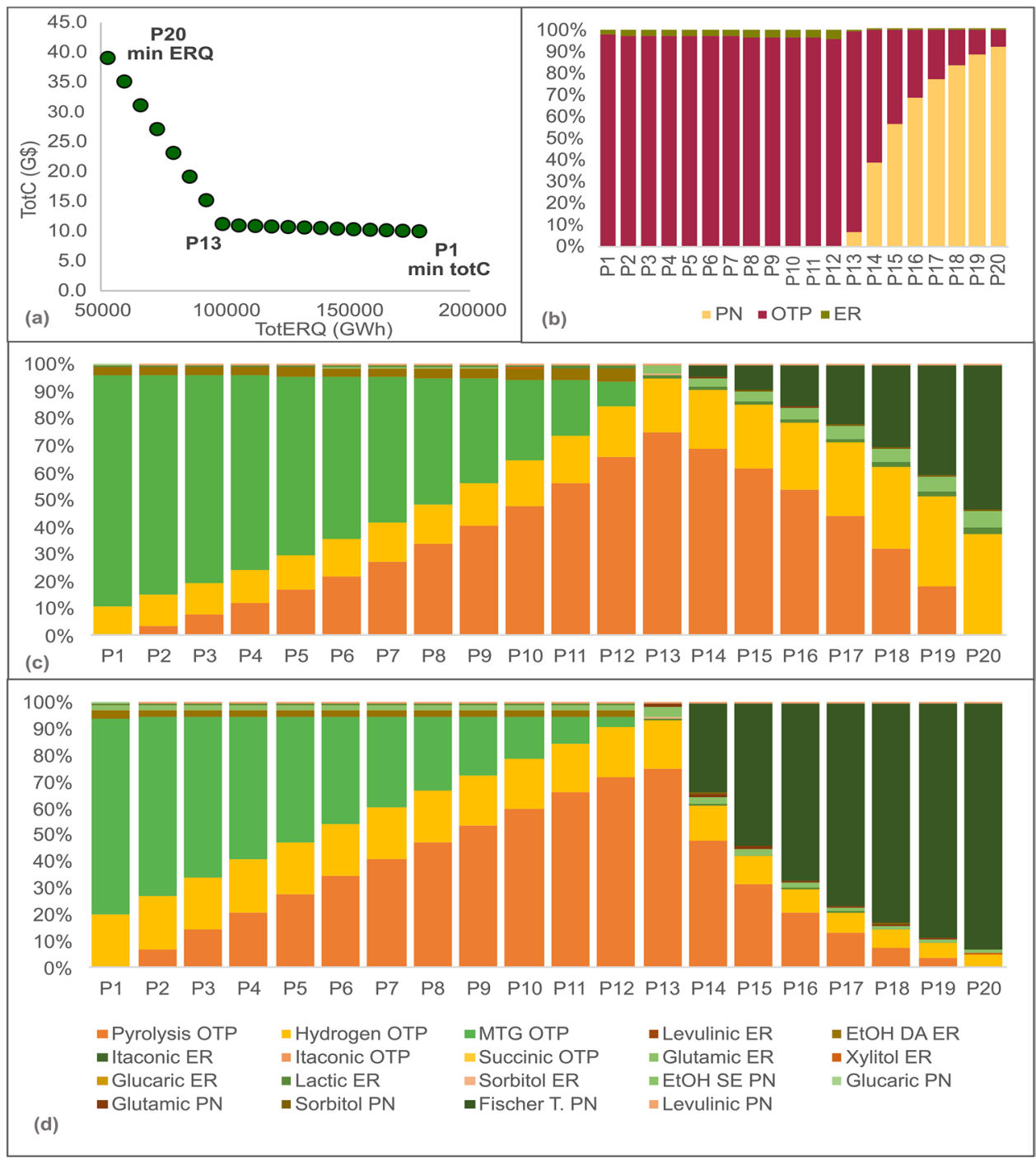

production are the major driver cost in all network solutions, $50 \%$ and $30 \%$ in $\mathrm{P} 1$ and $62 \%$ and $23 \%$ in P20, respectively. The reason is that ethanol and glutamic demand is higher than other building blocks one, 5200 and 1100 times higher than levulinic, which is a minor demand building block. Data for Fig. 7 can be found in Supplementary Material Tables 4 and 9.

\section{Conclusions}

Lignocellulosic biorefineries can make a strong contribution enabling the development of a sustainable, resourceefficient, and competitive economy. However, lignocellulosic biorefineries address the problem of economic profitability. To improve the competitiveness of biorefineries, it is necessary to broaden the product portfolio beyond biofuels and bioenergy. Furthermore, the proper biomass use is important for the effectiveness in a biorefinery, so the availability and price of three forest residues available in Spain, pine and eucalyptus residues and olive tree pruning, are considered in this work. To facilitate the right choice of feedstock-process-final product, this study proposed a network optimization methodology. The results suggest that building blocks, due to their good energy and economic performance, are good candidates to be included in the product portfolio of biorefineries when they are compared to advanced biofuels (lignocellulosic ethanol and gasoline) and hydrogen. In particular, the lactic acid is profitable in current market conditions from the three forest residues, while succinic and levulinic acids are close to the break-even point. In fact, in these three building blocks, their optimal routes (eucalyptus residues lactic, olive tree pruning succinic, and pine residues levulinic acids) remain stable in all solutions at the Pareto frontier from minimum cost to minimum energy requirement ones in limited feedstock availability case. In the Spain 
Fig. 7 (a) Pareto curve for building blocks optimal values considering limited feedstock availability. b Feedstock contribution in Pareto solutions. c Breakdown of energy requirement contribution by technology in Pareto solutions. d Breakdown of cost contribution by technology in Pareto solutions

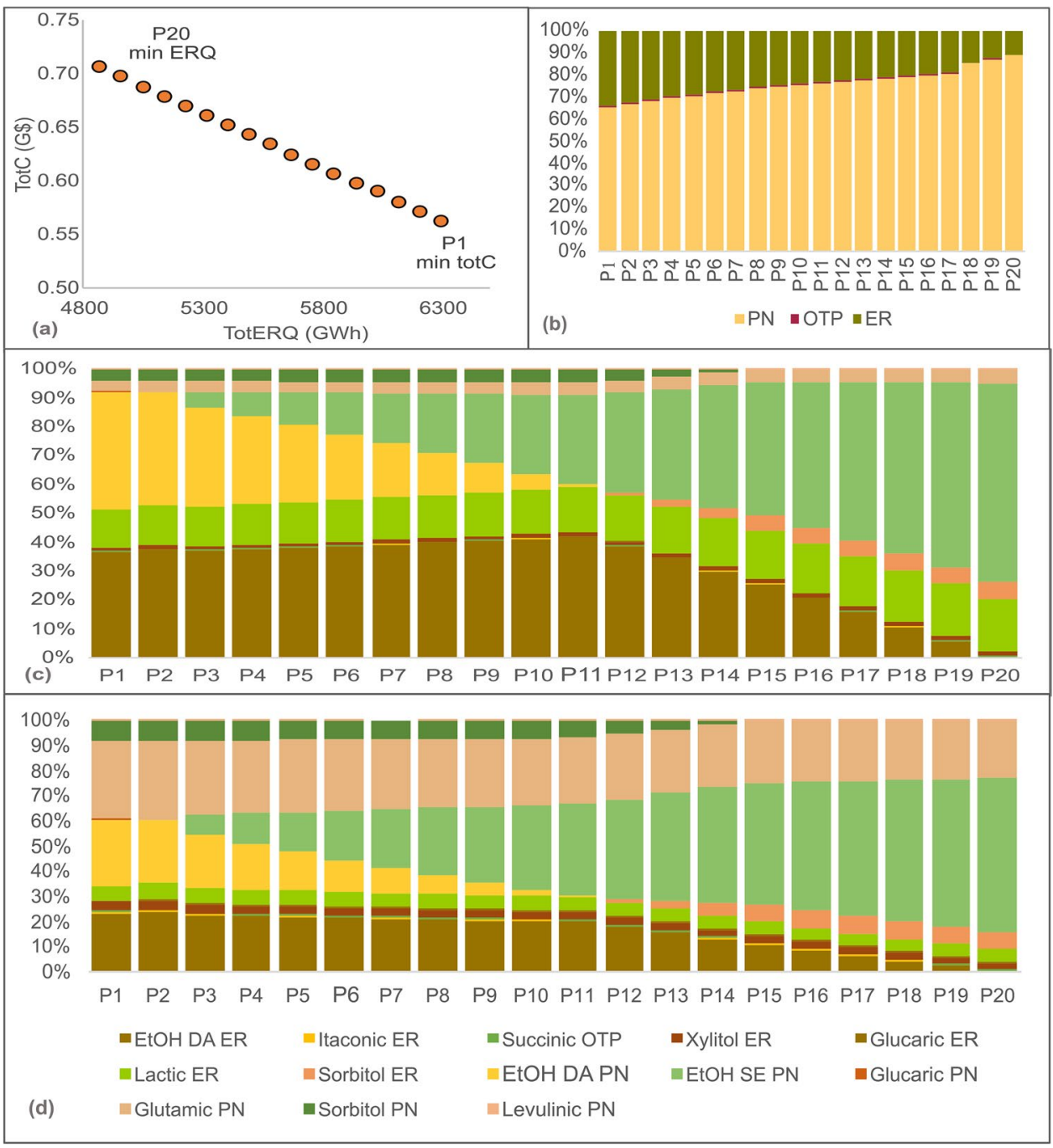

scenario and considering the completed portfolio (building blocks, advanced biofuels, and hydrogen), the results show that the demand could be satisfied with residual feedstock availability, and the minimum total cost would reach a value of $11.285 \mathrm{G} \$$. However, this minimum cost would suppose a cost increase of $32 \%$ over the market-price network solution, which means that these new technologies, although promising, need more research and development to be competitive to business as usual.

Supplementary Information The online version contains supplementary material available at https://doi.org/10.1007/s13399-021-02247-6.

Funding Open Access funding provided thanks to the CRUE-CSIC agreement with Springer Nature. The research leading to these results received funding from Comunidad Autónoma de Madrid (Spain) under Grant Agreement SUSTEC S2018/EMT-4348.

\section{Declarations}

Competing interest The authors declare no competing interests.

Open Access This article is licensed under a Creative Commons Attribution 4.0 International License, which permits use, sharing, adaptation, distribution and reproduction in any medium or format, as long as you give appropriate credit to the original author(s) and the source, provide a link to the Creative Commons licence, and indicate if changes were made. The images or other third party material in this article are included in the article's Creative Commons licence, unless indicated otherwise in a credit line to the material. If material is not included in the article's Creative Commons licence and your intended use is not permitted by statutory regulation or exceeds the permitted use, you will need to obtain permission directly from the copyright holder. To view a copy of this licence, visit http://creativecommons.org/licenses/by/4.0/.

\section{References}

1. FitzPatrick M, Champagne P, Cunningham MF, Whitney RA (2010) A biorefinery processing perspective: treatment of 
lignocellulosic materials for the production of value-added products. Bioresour Technol 101:8915-8922. https://doi.org/ 10.1016/j.biortech.2010.06.125

2. MITECO (2020) Plan Nacional Integrado de Energía y Clima 2021-2030. Minist para la Transic Ecológica y el Reto Demográfico, Gob España 25

3. Paris Agreement I Climate Action. https://ec.europa.eu/clima/ policies/international/negotiations/paris_en. Accessed $12 \mathrm{Jul}$ 2021

4. A Clean Planet for all COM (2018) 773 final. https://eur-lex. europa.eu/legal-content/EN/TXT/?uri=CELEX:52018DC0773. Accessed 12 Jul 2021

5. Tavares CS, Martins A, Miguel MG, et al (2020) Bioproducts from forest biomass II. Bioactive compounds from the steamdistillation by-products of Cupressus lusitanica Mill. and Cistus ladanifer L. wastes. Ind Crops Prod 158:. https://doi.org/10.1016/j. indcrop.2020.112991

6. van Schalkwyk DL, Mandegari M, Farzad S, Görgens JF (2020) Techno-economic and environmental analysis of bio-oil production from forest residues via non-catalytic and catalytic pyrolysis processes. Energy Convers Manag 213:112815. https://doi. org/10.1016/j.enconman.2020.112815

7. Sanford K, Chotani G, Danielson N, Zahn JA (2016) Scaling up of renewable chemicals. Curr Opin Biotechnol 38:112-122. https://doi.org/10.1016/j.copbio.2016.01.008

8. Superficies y producciones anuales de cultivos. https://www. mapa.gob.es/es/estadistica/temas/estadisticas-agrarias/agric ultura/superficies-producciones-anuales-cultivos/. Accessed $19 \mathrm{Jul} 2021$

9. Manzanares P, Ruiz E, Ballesteros M et al (2017) Residual biomass potential in olive tree cultivation and olive oil industry in Spain: valorization proposal in a biorefinery context. Spanish J Agric Res 15:1-12. https://doi.org/10.5424/sjar/2017153-10868

10. Agencia Extremeña de la Energía (2014) Los residuos agrícolas de poda. $1-32$

11. Díaz-Villanueva MJ, Cara-Corpas C, Ruiz-Ramos E, et al (2012) Olive tree pruning as an agricultural residue for ethanol production. Fermentation of hydrolysates from dilute acid pretreatment. Spanish J Agric Res 10:643. https://doi.org/10.5424/sjar/20121 03-2631

12. Susmozas A, Moreno AD, Romero-García JM et al (2019) Designing an olive tree pruning biorefinery for the production of bioethanol, xylitol and antioxidants: a techno-economic assessment. Holzforschung 73:15-23. https://doi.org/10.1515/hf-2018-0099

13. Anuario de Estadística Forestal 2018. https://www.miteco.gob. es/en/biodiversidad/estadisticas/forestal_anuario_2018.aspx. Accessed 19 Jul 2021

14. Grupo Empresarial Ence (2009) Sustainable forest management and eucalyptus. Grup. Empres. Ence 1-76

15. Eisenbies MH, Vance ED, Aust WM, Seiler JR (2009) Intensive utilization of harvest residues in southern pine plantations: quantities available and implications for nutrient budgets and ustainable Site Productivity. Bioenergy Res 2:90-98. https://doi.org/10.1007/ s12155-009-9036-Z

16. El eucalipto. https://compramosmadera.es/index.php/es/el-eucal ipto-2. Accessed 19 Jul 2021

17. LIFE 3.0 - LIFE Project Public Page. https://webgate.ec.europa. $\mathrm{eu} /$ life/publicWebsite/index.cfm?fuseaction=search.dspPage\&n proj_id=4645. Accessed 19 Jul 2021

18. Vargas R, Vecchietti A (2018) Modeling the thermochemical pretreatment of eucalyptus globulus for bioethanol production. Ind Eng Chem Res 57:12458-12467. https://doi.org/10.1021/acs.iecr. $8 \mathrm{~b} 02706$

19. Romaní A, Garrote G, Ballesteros I, Ballesteros M (2013) Second generation bioethanol from steam exploded Eucalyptus globulus wood. Fuel 111:66-74. https://doi.org/10.1016/j.fuel.2013.04.076
20. Tagomori IS, Rochedo PRR, Szklo A (2019) Techno-economic and georeferenced analysis of forestry residues-based FischerTropsch diesel with carbon capture in Brazil. Biomass Bioenerg 123:134-148. https://doi.org/10.1016/j.biombioe.2019.02.018

21. Castro JF, Parra C, Yáñez-S M et al (2013) Optimal pretreatment of Eucalyptus globulus by hydrothermolysis and alkaline extraction for microbial production of ethanol and xylitol. Ind Eng Chem Res 52:5713-5720. https://doi.org/10.1021/ie301859x

22. Mendes CVT, Vergara P, Carbajo JM et al (2020) Bioconversion of pine stumps to ethanol: pretreatment and simultaneous saccharification and fermentation. Holzforschung 74:212-216. https://doi.org/10.1515/hf-2018-0126

23. Vaid S, Nargotra P, Bajaj BK (2018) Consolidated bioprocessing for biofuel-ethanol production from pine needle biomass. Environ Prog Sustain Energy 37:546-552

24. de Jong E, Higson A, Walsh P, Wellisch M (2020) Bio-based chemicals. IEA Bioenergy Task 42

25. Werpy T, Petersen G (2004) Top value added chemicals from biomass: volume $\mathrm{i}$-- results of screening for potential candidates from sugars and synthesis gas. Office of Scientific and Technical Information (OSTI). Off Sci Tech Inf 69. https://doi.org/10.2172/ 15008859

26. Bozell JJ, Petersen GR (2010) Technology development for the production of biobased products from biorefinery carbohydratesthe US Department of Energy's “top 10” revisited. Green Chem 12:539-555. https://doi.org/10.1039/b922014c

27. E4tech (2017) Advanced drop-in biofuels: UK production capacity outlook to 2030.83

28. Kargbo H, Harris JS, Phan AN (2021) "Drop-in" fuel production from biomass: critical review on techno-economic feasibility and sustainability. Renew Sustain Energy Rev 135:110168. https://doi. org/10.1016/j.rser.2020.110168

29. Dutta A, Sahir A, Tan E, et al (2015) Process design and economics for the conversion of lignocellulosic biomass to hydrocarbon fuels. Thermochemical Research Pathways with In Situ and Ex Situ Upgrading of Fast Pyrolysis Vapors. Nrel 275

30. Thilakaratne R, Brown T, Li Y et al (2014) Mild catalytic pyrolysis of biomass for production of transportation fuels: a technoeconomic analysis. Green Chem 16:627-636. https://doi.org/10. 1039/c3gc41314d

31. Mohammed IY, Abakr YA, Mokaya R (2019) Integrated biomass thermochemical conversion for clean energy production: process design and economic analysis. J Environ Chem Eng 7:103093. https://doi.org/10.1016/j.jece.2019.103093

32. Trippe F, Fröhling M, Schultmann F et al (2013) Comprehensive techno-economic assessment of dimethyl ether (DME) synthesis and Fischer-Tropsch synthesis as alternative process steps within biomass-to-liquid production. Fuel Process Technol 106:577-586. https://doi.org/10.1016/j.fuproc.2012.09.029

33. Dutta A, Talmadge M (2011) Process design and economics for conversion of lignocellulosic biomass to ethanol. NREL Tech Rep NREL/TP-5100-51400 187

34. Phillips SD, Tarud JK, Biddy MJ (2011) Gasoline from wood via integrated gasification, synthesis, and methanol-to- gasoline technologies. Energy. NREL/TP-5100-47594

35. Ruddy DA, Hensley JE, Nash CP et al (2019) Methanol to highoctane gasoline within a market-responsive biorefinery concept enabled by catalysis. Nat Catal 2:632-640. https://doi.org/10. 1038/s41929-019-0319-2

36. Spath P, Ringer M (2005) Biomass to hydrogen production detailed design and economics utilizing the battele columbus laboratory indirectly-heated gasifier. Nrel

37. Binder M, Kraussler M KM (2018) Hydrogen from biomass

38. Robak K, Balcerek M (2020) Current state-of-the-art in ethanol production from lignocellulosic feedstocks. Microbiol Res 240:126534. https://doi.org/10.1016/j.micres.2020.126534 
39. Hayes DJM (2013) Second-generation biofuels: why they are taking so long. Wiley Interdiscip Rev Energy Environ 2:304-334. https://doi.org/10.1002/wene.59

40. E4tech R-C and W (2015) From the sugar platform to biofuels and biochemicals. Final Rep. Eur. Comm. Dir. Energy 183

41. Chandel AK, Garlapati VK, Jeevan Kumar SP et al (2020) The role of renewable chemicals and biofuels in building a bioeconomy. Biofuels, Bioprod Biorefining 14:830-844. https://doi.org/ 10.1002/bbb. 2104

42. Rahmati S, Doherty W, Dubal D et al (2020) Pretreatment and fermentation of lignocellulosic biomass: reaction mechanisms and process engineering. React Chem Eng 5:2017-2047. https://doi. org/10.1039/d0re00241k

43. Humbird D, Davis R, Tao L, et al (2011) Process design and economics for conversion of lignocellulosic biomass to ethanol. NREL Tech Rep NREL/TP-5100-51400 303:275-3000

44. da Silva ARG, Torres Ortega CE, Rong BG (2016) Techno-economic analysis of different pretreatment processes for lignocellulosic-based bioethanol production. Bioresour Technol 218:561570. https://doi.org/10.1016/j.biortech.2016.07.007

45. Kazi FK, Fortman J, Anex R (2010) Techno-economic analysis of biochemical scenarios for production of cellulosic ethanol technoeconomic analysis of biochemical scenarios for production of cellulosic ethanol. Natl Renew Energy Lab

46. Wingren A, Galbe M, Zacchi G (2008) Energy considerations for a SSF-based softwood ethanol plant. Bioresour Technol 99:21212131. https://doi.org/10.1016/j.biortech.2007.05.058

47. Wingren A, Galbe M, Zacchi G (2003) Techno-economic evaluation of producing ethanol from softwood: comparison of SSF and SHF and identification of bottlenecks. Biotechnol Prog 19:11091117. https://doi.org/10.1021/bp0340180

48. Lu J, Li J, Gao H et al (2021) Recent progress on bio-succinic acid production from lignocellulosic biomass. World J Microbiol Biotechnol 37:1-8. https://doi.org/10.1007/s11274-020-02979-Z

49. Nieder-Heitmann M, Haigh K, Görgens JF (2019) Process design and economic evaluation of integrated, multi-product biorefineries for the co-production of bio-energy, succinic acid, and polyhydroxybutyrate (PHB) from sugarcane bagasse and trash lignocelluloses. Biofuels, Bioprod Biorefining 13:599-617. https://doi. org/10.1002/bbb.1972

50. Giuliano A, Poletto M, Barletta D (2016) Process optimization of a multi-product biorefinery: the effect of biomass seasonality. Chem Eng Res Des 107:236-252. https://doi.org/10.1016/j.cherd. 2015.12.011

51. Liu C, Lu X, Yu Z et al (2020) Production of levulinic acid from cellulose and cellulosic biomass in different catalytic systems. Catalysts 10:1-22. https://doi.org/10.3390/catal10091006

52. Hayes DJ, Fitzpatrick S, Hayes MHB, Ross JRH (2006) The biofine process - production of levulinic acid, furfural, and formic acid from lignocellulosic feedstocks. Biorefineries - Ind Process Prod 1:139-164

53. Kapanji KK, Farzad S, Görgens JF (2021) Life cycle and sustainability assessments of biorefineries producing glucaric acid, sorbitol or levulinic acid annexed to a sugar mill. J Clean Prod 295:. https://doi.org/10.1016/j.jclepro.2021.126339

54. Kapanji KK, Haigh KF, Görgens JF (2019) Techno-economic analysis of chemically catalysed lignocellulose biorefineries at a typical sugar mill: sorbitol or glucaric acid and electricity coproduction. Bioresour Technol 289:121635. https://doi.org/10. 1016/j.biortech.2019.121635

55. Thaore VB, Armstrong RD, Hutchings GJ et al (2020) Sustainable production of glucaric acid from corn stover via glucose oxidation: an assessment of homogeneous and heterogeneous catalytic oxidation production routes. Chem Eng Res Des 153:337-349. https://doi.org/10.1016/j.cherd.2019.10.042
56. Özüdoğru HMR, Haigh KF, Görgens JF (2019) Industrial crops \& products techno-economic analysis of product biorefineries utilizing sugarcane lignocelluloses : xylitol, citric acid and glutamic acid scenarios annexed to sugar mills with electricity co-production. Ind Crop Prod 133:259-268. https://doi.org/10.1016/j.inder op.2019.03.015

57. Felipe Hernández-Pérez A, de Arruda PV, Sene L et al (2019) Xylitol bioproduction: state-of-the-art, industrial paradigm shift, and opportunities for integrated biorefineries. Crit Rev Biotechnol 39:924-943. https://doi.org/10.1080/07388551.2019.1640658

58. Magalhães AI, de Carvalho JC, Thoms JF et al (2019) Technoeconomic analysis of downstream processes in itaconic acid production from fermentation broth. J Clean Prod 206:336-348. https://doi.org/10.1016/j.jclepro.2018.09.204

59. Kerssemakers AAJ, Doménech P, Cassano M, et al (2020) Production of itaconic acid from cellulose pulp: feedstock feasibility and process strategies for an efficient microbial performance. Energies 13:. https://doi.org/10.3390/en13071654

60. Biddy MJ, Scarlata CJ, Kinchin CM (2016) Chemicals from biomass: a market assessment of bioproducts with near-term potential. NREL Rep. https://doi.org/10.2172/1244312

61. Li Y, Bhagwat SS, Cortés-Penã YR et al (2021) Sustainable lactic acid production from lignocellulosic biomass. ACS Sustain Chem Eng 9:1341-1351. https://doi.org/10.1021/acssuschem eng.0c08055

62. Liu G, Sun J, Zhang J, et al (2015) High titer L -lactic acid production from corn stover with minimum wastewater generation and techno-economic evaluation based on Aspen plus modeling. 198:803-810. https://doi.org/10.1016/j.biortech.2015.09.098

63. Kokossis AC, Yang A (2010) On the use of systems technologies and a systematic approach for the synthesis and the design of future biorefineries. Comput Chem Eng 34:1397-1405. https://doi.org/10.1016/j.compchemeng.2010.02.021

64. Pham V, El-Halwagi M (2012) Process synthesis and optimization of biorefinery configurations. AIChE J 58:1212-1221. https://doi.org/10.1002/aic.12640

65. Murillo-Alvarado PE, Ponce-Ortega JM, Serna-González M et al (2013) Optimization of pathways for biorefineries involving the selection of feedstocks, products, and processing steps. Ind Eng Chem Res 52:5177-5190. https://doi.org/10.1021/ie303 $428 \mathrm{v}$

66. König A, Ulonska K, Mitsos A, Viell J (2019) Optimal applications and combinations of renewable fuel production from biomass and electricity. Energy Fuels 33:1659-1672. https://doi.org/ 10.1021/acs.energyfuels.8b03790

67. You C, Han S, Kim J (2021) Integrative design of the optimal biorefinery and bioethanol supply chain under the water-energyfood-land (WEFL) nexus framework. Energy 228:120574. https:// doi.org/10.1016/j.energy.2021.120574

68. Cheali P, Posada JA, Gernaey KV (2015) Upgrading of lignocellulosic biorefinery to value- added chemicals : sustainability and economics of bioethanol-derivatives. Biomass Bioenerg 75:282300. https://doi.org/10.1016/j.biombioe.2015.02.030

69. Álvarez del Castillo-Romo A, Morales-Rodriguez R, RománMartínez A (2018) Multiobjective optimization for the socio-ecoefficient conversion of lignocellulosic biomass to biofuels and bioproducts. Clean Technol Environ Policy 20:603-620. https:// doi.org/10.1007/s10098-018-1490-x

70. Giuliano A, Cerulli R, Poletto M et al (2016) Process pathways optmization for lignocellulosic biorefinery producing levulinic acid, succinic and ethanol. Ind Eng Chem Res 50:10699-10717. https://doi.org/10.1021/acs.iecr.6b01454

71. Ng RTL, Maravelias CT (2017) Design of biofuel supply chains with variable regional depot and biorefinery locations. Renew Energy 100:90-102. https://doi.org/10.1016/j.renene.2016.05.009 
72. Serrano A, Faulin J, Astiz P et al (2015) Locating and designing a biorefinery supply chain under uncertainty in Navarre: a stochastic facility location problem case. Transp Res Procedia 10:704-713. https://doi.org/10.1016/j.trpro.2015.09.024

73. Bowling IM, Ponce-Ortega JM, El-Halwagi MM (2011) Facility location and supply chain optimization for a biorefinery. Ind Eng Chem Res 50:6276-6286. https://doi.org/10.1021/ie101921y

74. You F, Grossmann IE (2008) Design of responsive supply chains under demand uncertainty. Comput Chem Eng 32:3090-3111. https://doi.org/10.1016/j.compchemeng.2008.05.004

75. Bhosekar A, Badejo O, Ierapetritou M (2021) Modular supply chain optimization considering demand uncertainty to manage risk. AIChE J 67:1-15. https://doi.org/10.1002/aic.17367

76. Cambero C, Sowlati $T$ (2016) Incorporating social benefits in multi-objective optimization of forest-based bioenergy and biofuel supply chains. Appl Energy 178:721-735. https://doi.org/10. 1016/j.apenergy.2016.06.079

77. Santibañez-Aguilar JE, Morales-Rodriguez R, González-Campos JB, Ponce-Ortega JM (2016) Stochastic design of biorefinery supply chains considering economic and environmental objectives. J Clean Prod 136:224-245. https://doi.org/10.1016/j.jclepro.2016. 03.168

78. Calvo-Serrano R, Guo M, Pozo C et al (2019) Biomass conversion into fuels, chemicals, or electricity? a network-based life cycle optimization approach applied to the European Union. ACS Sustain Chem Eng 7:10570-10582. https://doi.org/10.1021/acssu schemeng.9b01115

79. Santibañez-Aguilar JE, González-Campos JB, Ponce-Ortega JM et al (2014) Optimal planning and site selection for distributed multiproduct biorefineries involving economic, environmental and social objectives. J Clean Prod 65:270-294. https://doi.org/10. 1016/j.jclepro.2013.08.004

80. Cheali P, Gernaey KV, Sin G (2014) Towards a computer-aided synthesis and design of biorefinery networks - data collection and management using a generic modeling approach. ACS Sustain Chem Eng 2:19-29. https://doi.org/10.1021/sc400179f
81. Kim J, Sen SM, Maravelias CT (2013) An optimization-based assessment framework for biomass-to-fuels conversion strategies. Energy Environ Sci 6:1093-1104. https://doi.org/10.1039/C3EE2 $4243 \mathrm{~A}$

82. Schack D, Rihko-Struckmann L, Sundmacher K (2018) Linear programming approach for structure optimization of renewableto-chemicals (R2Chem) production networks. Ind Eng Chem Res 57:9889-9902. https://doi.org/10.1021/acs.iecr.7b05305

83. Stephen JD, Mabee WE, Saddler JN (2012) Will second-generation ethanol be able to compete with fi rst-generation ethanol? Opportunities for cost reduction. Biofuels, Bioprod Biorefining 6:159-176. https://doi.org/10.1002/bbb.331

84. Ng KS, Sadhukhan J (2011) Techno-economic performance analysis of bio-oil based Fischer-Tropsch and CHP synthesis platform. Biomass Bioenerg 35:3218-3234. https://doi.org/10.1016/j.biomb ioe.2011.04.037

85. Kumar D, Murthy GS (2011) Impact of pretreatment and downstream processing technologies on economics and energy in cellulosic ethanol production. Biotechnol Biofuels 4:. https://doi.org/ 10.1186/1754-6834-4-27

86. Baral NR, Shah A (2017) Comparative techno-economic analysis of steam explosion, dilute sulfuric acid, ammonia fiber explosion and biological pretreatments of corn stover. Bioresour Technol 232:331-343. https://doi.org/10.1016/j.biortech.2017.02.068

87. Liu G, Bao J (2017) Maximizing cellulosic ethanol potentials by minimizing wastewater generation and energy consumption: competing with corn ethanol. Bioresour Technol 245:18-26. https:// doi.org/10.1016/j.biortech.2017.08.070

88. Producer price index (PPI). https://www.bls.gov/ppi/. Accessed 3 Dec 2021

Publisher's note Springer Nature remains neutral with regard to jurisdictional claims in published maps and institutional affiliations. 